\title{
Comparison of NF-RO and RO-NF for the Treatment of Mature Landfill Leachates: A Guide for Landfill Operators ${ }^{\dagger}$
}

\author{
Sreenivasan Ramaswami * (D), Joachim Behrendt and Ralf Otterpohl \\ Institute of Wastewater Management and Water Protection, Hamburg University of Technology (TUHH), \\ Eissendorfer Str. 42, 21073 Hamburg, Germany; j.behrendt@tuhh.de (J.B.); ro@tuhh.de (R.O.) \\ * Correspondence: sreeni@tuhh.de; Tel.: +49-40-42878-2767 \\ † Findings of this work were presented at Sardinia Symposium 2017. Ramaswami, S.; Behrendt, J.; \\ Otterpohl, R. (2017). Treatment of mature landfill leachate-RO-NF or NF-RO? In the proceedings of: Sardinia \\ 2017-Sixteenth International Waste Management and Landfill Symposium, 2-6 October 2017, Cagliari, Italy. \\ ISBN: 9788862650106.
}

Received: 27 February 2018; Accepted: 20 March 2018; Published: 21 March 2018

\begin{abstract}
Reverse osmosis (RO) and nanofiltration (NF) are among the state-of-the-art technologies for treating landfill leachates. Due to the complexity and variance in the composition of leachates, numerous combinations of multiple technologies are used for their treatment. One process chain for the treatment of raw leachate is $\mathrm{RO}$ followed by further concentration of RO-retentate using NF (RO-NF scheme). The aptness of this process train used by some landfill sites around the world (usually with the aim of volume reduction so as to re-inject the concentrate into the landfill) is questionable. This study investigated two schemes RO-NF and NF-RO (nanofiltration of raw leachate followed by reverse osmosis of NF permeate) to identify their merits/demerits. Experiments were conducted in bench scale using commercial membranes: DOW Filmtec NF270 and SW30HR. Filtration trials were performed at different pressures to compare the water and solute transports in the individual stages of the two schemes. Based on the water fluxes and compositions of retentates and permeates; osmotic pressures, energy demands, and other possible operational advantages were discussed. NF-RO offers some advantages and flexibility for leachate treatment besides being energy efficient compared to RO-NF, wherein osmotic pressure steadily increases during operation in turn increasing operation and maintenance costs.
\end{abstract}

Keywords: landfill leachate; monovalent ions; nanofiltration; organics; reverse osmosis

\section{Introduction}

Landfill leachates are one among the most polluted wastewaters, characterized by high chemical oxygen demand (COD) and ammonia content. The characteristics of organics and their concentration, as well as the concentration of $\mathrm{N}^{-\mathrm{NH}_{4}}{ }^{+}$depends on the landfill age [1]. Additionally, depending on the type of waste deposited, they can contain high concentrations of heavy metals (e.g., $\mathrm{Zn}^{2+}, \mathrm{Cr}^{3+}, \mathrm{Ni}^{2+}$, $\mathrm{Cd}^{2+}, \mathrm{Pb}^{2+}, \mathrm{As}^{3+}$, or their speciations), other metal ions $\left(\mathrm{Na}^{+}, \mathrm{K}^{+}, \mathrm{Ca}^{2+}, \mathrm{Mg}^{2+}, \mathrm{Fe}^{2+}\right.$, and $\left.\mathrm{Al}^{3+}\right)$ and anions like $\mathrm{Cl}^{-}, \mathrm{SO}_{4}{ }^{2-}, \mathrm{PO}_{4}{ }^{3-}$, etc. Numerous technologies, in many possible combinations of them, have been studied and used for leachate treatment [2-4].

Reverse osmosis is a state-of-the-art technology for the treatment of landfill leachates. RO process (using cellulose acetate membrane) was studied for treatment of landfill leachate within two decades from its discovery and was reported to be the most effective method for treating leachates [5]. By the mid-1980s, RO systems had already penetrated significantly into the market of leachate treatment $[6,7]$. The technology is highly promising and efficient for the treatment of landfill leachates having rejection 
coefficients on an average greater than $0.98[3,6,8,9]$ for all pollutants (esp. organics and heavy metals), thus providing high quality permeate. RO systems were installed in more than 100 landfill sites in northern Europe, North America, and the Far East during the last decade [10].

Recirculation of leachate constituents by controlled re-injection of RO concentrate into the landfill has been researched and practiced widely. It has been shown to enhance the biodegradation rate or landfill gas production in young landfills, which contain a high portion of biodegradable organic matter [11-14]. However, it is also reported that constituents like ammonia, chloride, and metals are not removed by recirculation [11,15], due to which this cannot be a sustainable solution. Therefore, re-injection of $\mathrm{RO}$ retentate cannot be beneficial in the case of old landfills producing methanogenic leachate (containing no biodegradable COD) and would likely result in an increase in strength of the leachate. For this reason, recirculation of methanogenic leachates is forbidden by the German Landfill Ordinance 2009, unless the landfill operator can prove the gain of any benefit from doing so [16].

The leachate considered in this study is from the hazardous waste landfill site at Ihlenberg, Germany; one of the largest and most advanced landfills in Europe [7]. The site with a landfill area of 113 hectares $\left(1.13 \mathrm{~km}^{2}\right)$ was commissioned in 1983 with a total capacity of 26 million cubic meters [17]. By the end of 1989, an RO system with $36 \mathrm{~m}^{3} / \mathrm{h}$ capacity was installed for treating the raw leachate, recovering up to $80-85 \%$ clean water and re-injecting the retentate [7]. Some studies at the Ihlenberg dumpsite in the past $[7,9,18,19]$ have focused on minimizing the concentrate volume to be re-injected, as retentate disposal is very cost intensive. Some of them investigated the application of reverse osmosis at 200 bar while some investigated a combination of $\mathrm{RO}$, high pressure $\mathrm{RO}$ and high pressure NF (as in Figure 1a) for reducing the volume of concentrate as low as possible. To comply with the ban on retentate recirculation, the $\mathrm{RO}$ concentrate currently gets treated further as in Figure 1a, the aptness of which (the process train) is questionable.
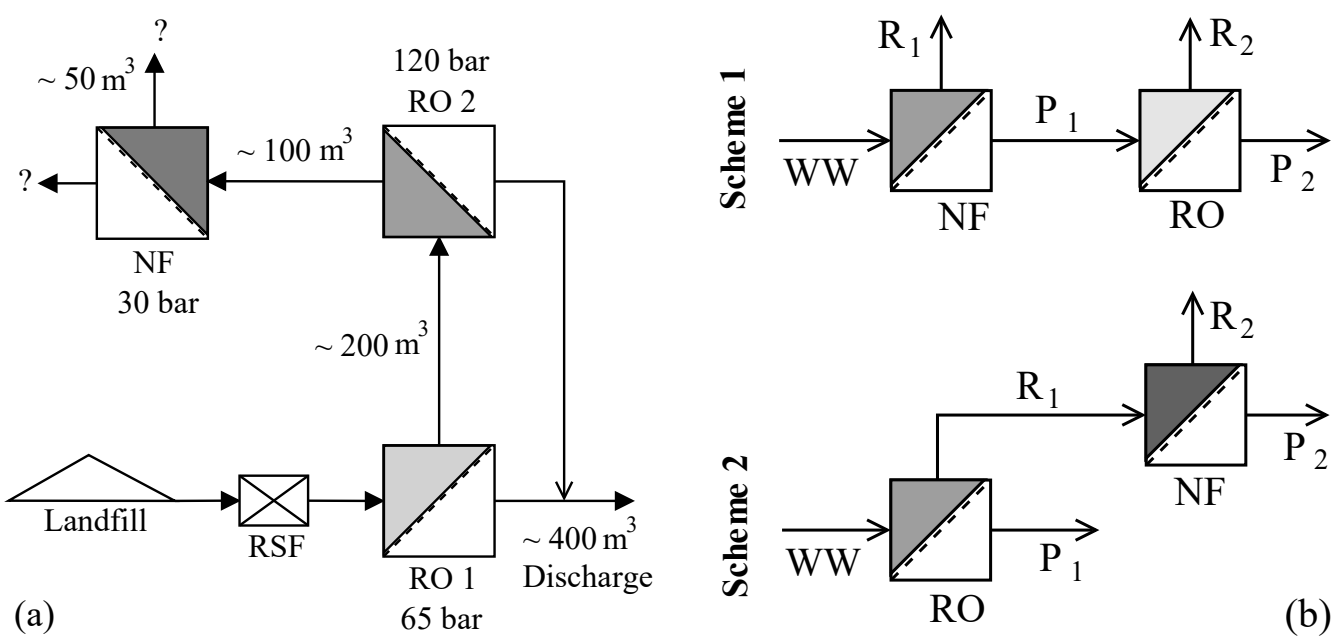

Figure 1. (a) Treatment scheme at landfill site (based on IAG [17] and Rautenbach et al. [19]) (RSF—rapid sand filtration); (b) Integration options investigated in this study (WW-wastewater/leachate, $\mathrm{R}$-Retentate, $\mathrm{P}$-Permeate).

This study investigates the two integration options: NF-RO and RO-NF for this scenario, as illustrated in Figure 1b. Scientists involved in the field of membrane technologies would typically recommend NF-RO over RO-NF [20,21]. However, landfill operators and leachate professionals, who do not necessarily possess a good knowhow of nanofiltration and reverse osmosis processes, will not be in a position to analyze these two schemes. The practice of nanofiltration of RO concentrate has been reported in literature $[19,22]$ for landfill sites like Halle Lochau (Germany), Goerlitz (Germany), and Yachio Town (Japan). The first author of this paper came to know of similar other cases at the Sardinia Symposium 2017 (personal communication, leachate professional). 
NF compared to RO can be operated at lower pressures; offers higher fluxes; rejects organics and multivalent ions selectively; and incurs lower investment, operation, and maintenance costs. Due to these reasons, numerous studies in the recent past have preferred NF over RO and explored its ability for the treatment of landfill leachates [6,23-31]. However, no study could be identified, which investigated a combination of NF and RO (NF-RO) for treating landfill leachates. Integration of technologies has been emphasized for achieving efficient and economic treatment of landfill leachates [24,28,32-35], which could also offer more flexibility and advantages for the individual processes in the process chain [35].

This study aims to investigate the two combinations (NF-RO and RO-NF) for the treatment of old landfill leachates, and to identify the merits/demerits of the two process trains. Experiments were conducted in bench-scale to demonstrate the differences between the two schemes, with respect to water fluxes (energy requirements), rejection of solutes, and other operational advantages. This paper critically analyses the two integration options, and discusses some fundamental properties and transport characteristics of nanofiltration and reverse osmosis membranes applied to leachate treatment.

\section{Materials and Methods}

The experiments were carried out in the laboratories for drinking water research at the Institute of Water Resources and Water Supply, TUHH. For this reason the wastewater was prepared synthetically by dissolving known weights of the compounds (as in Table 1) in deionized water to have a composition resembling that of the raw leachate from the Ihlenberg landfill site (Table 2). This was done to avoid any kind of contamination of the laboratories from the hazardous landfill leachate. Sodium salt of humic acid, purchased from Carl Roth $\mathrm{GmbH}$ (Karlsruhe, Germany), had a humic acid (HA) content of about $45-65 \%$. The HA salt had a sodium content of about $8-9 \%$ as $\mathrm{Na}_{2} \mathrm{O}$ (Carl Roth $\mathrm{GmbH}$, personal communication). The HA salt was measured to have a total organic carbon (TOC) content of $300 \mathrm{mg} / \mathrm{g}$. All other solutes used were of analytical grade.

Table 1. Solutes used for the preparation of $1 \mathrm{~L}$ synthetic leachate.

\begin{tabular}{|c|c|c|c|}
\hline Solute & Weight (in g) & Solute & Weight (in g) \\
\hline $\mathrm{CaCl}_{2} \cdot 2 \mathrm{H}_{2} \mathrm{O}$ & 0.84 & $\mathrm{NaHCO}_{3}$ & 0.45 \\
\hline $\mathrm{KCl}$ & 2.10 & $\mathrm{Na}_{2} \mathrm{SO}_{4}$ & 0.83 \\
\hline $\mathrm{MgCl}_{2} \cdot 6 \mathrm{H}_{2} \mathrm{O}$ & 0.68 & $\mathrm{NH}_{4} \mathrm{HCO}_{3}$ & 2.55 \\
\hline $\mathrm{NaCl}$ & 6.73 & Na-Humic acid & 2.80 \\
\hline
\end{tabular}

Table 2. Composition of raw leachate-major solutes (after analyses made by landfill operator).

\begin{tabular}{|c|c|c|c|}
\hline \multicolumn{4}{|c|}{ Ions $(\mathrm{mg} / \mathrm{L})$} \\
\hline $\mathrm{Ca}^{2+}$ & 230 & $\mathrm{Mg}^{2+}$ & 81 \\
\hline $\mathrm{Cl}^{-}$ & 5800 & $\mathrm{~N}-\mathrm{NH}_{4}{ }^{+}$ & 580 \\
\hline $\mathrm{HCO}_{3}^{-}$ & 3447 & $\mathrm{Na}^{+}$ & 3100 \\
\hline $\mathrm{K}^{+}$ & 1100 & $\mathrm{SO}_{4}^{2-}$ & 560 \\
\hline \multicolumn{4}{|c|}{ Sum parameters } \\
\hline $\mathrm{pH}$ & 8.01 & Conductivity $(\mu \mathrm{S} / \mathrm{cm})$ & 23.5 \\
\hline $\mathrm{COD}(\mathrm{mg} / \mathrm{L})$ & 1900 & TOC $(\mathrm{mg} / \mathrm{L})$ & 840 \\
\hline
\end{tabular}

The HA salt had not dissolved completely, even over several hours of stirring. The synthetic leachate was filtered using a folded filter paper (Carl Roth 600P-500, $13 \mu \mathrm{m}$ pore diameter) to remove the undissolved HA salt. The filtrate was analyzed for $\mathrm{N}_{-} \mathrm{NH}_{4}{ }^{+}$; total inorganic carbon (TIC), TOC, and COD concentrations; absorbance at $254 \mathrm{~nm}$ (Abs254); and conductivity, and used for all the experiments. 
A schematic of the experimental setup used in the study is shown in Figure 2. HP4750 Stirred Cell (Sterlitech Corporation, Kent, Washington, DC, USA) was used to carry out the filtration trials in dead-end mode providing an active membrane area of $14.6 \mathrm{~cm}^{2}$. Nitrogen gas flowing through a digital manometer (Pressure Gauge Digital with Ceramic Sensor Element, Battery Powered MAN-SD from Kobold Messring GmbH, Hofheim, Germany) and pressure regulators (Swagelok, OH, USA) was used to apply the desired pressure inside the cell. The weight of the collected permeate was measured using an Acculab ATL-2202 balance (Sartorius AG, Goettingen, Germany) and recorded every $10 \mathrm{~s}$. All experiments were carried out at ambient temperature $\left(22 \pm 1^{\circ} \mathrm{C}\right)$ The recorded volume flow rate was used to estimate the temperature corrected permeate flux (using GE Water [36]) at $25^{\circ} \mathrm{C}$.

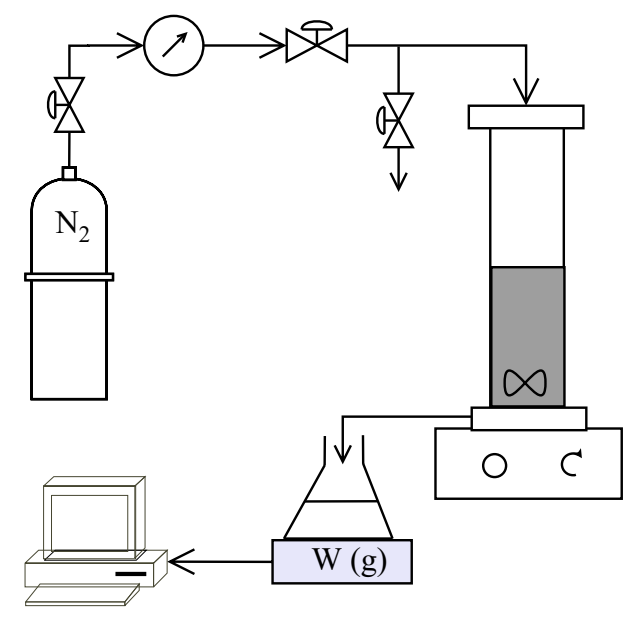

Figure 2. Schematic of experimental setup used in the study.

Polyamide thin film composite membranes Dow Filmtec SW30HR and NF270 were used for performing the reverse osmosis and nanofiltration experiments, respectively. The membranes were cut in circles of $50 \mathrm{~mm}$ diameter and stored in pure water (type 1, $0.05 \mu \mathrm{S} / \mathrm{cm}$ conductivity, produced using a Direct-Q ${ }^{\circledR} 5$ UV-R system, Merck Millipore, Darmstadt, Germany) at $4{ }^{\circ} \mathrm{C}$ for more than $24 \mathrm{~h}$ to allow swelling. Two types of experiments were conducted, as illustrated in Figure 1b, to study the individual processes and their combination for treating the synthetic leachate. A total of eight trials were carried out as in Table 3 using virgin membranes for each experiment. Before each experiment, pure water was filtered through the respective membrane at the desired operating pressure +5 bar (OP +5 bar) until a steady permeate flux was achieved. This would result in a stable membrane structure (after subjecting the membrane to possible compaction at that pressure) before operation and also enable the determination of pure water permeability of the membranes.

Table 3. Summary of experiments.

\begin{tabular}{|c|c|c|c|c|c|c|c|c|}
\hline \multirow{4}{*}{ scheme $1 \mathrm{NF} \rightarrow \mathrm{RO}$} & \multicolumn{4}{|l|}{ NF at 20 bar } & \multicolumn{4}{|c|}{$\mathrm{RO}$ at 60 bar } \\
\hline & $\mathrm{F}=200$ & $\mathrm{R}=80$ & $\mathrm{cf}=2.50$ & $\mathrm{P}=120$ & $\mathrm{~F}=100$ & $R=50$ & $\mathrm{cf}=2.00$ & $\mathrm{P}=50$ \\
\hline & \multicolumn{4}{|l|}{$\mathrm{NF}$ at $30 \mathrm{bar}$} & \multicolumn{4}{|c|}{ RO at 50 bar } \\
\hline & $\mathrm{F}=200$ & $\mathrm{R}=77$ & $\mathrm{cf}=2.60$ & $\mathrm{P}=123$ & $\mathrm{~F}=100$ & $\mathrm{R}=47$ & $\mathrm{cf}=2.13$ & $\mathrm{P}=53$ \\
\hline \multirow{4}{*}{ scheme $2 \mathrm{RO} \rightarrow \mathrm{NF}$} & \multicolumn{4}{|l|}{ RO at 60 bar } & \multicolumn{4}{|c|}{$\mathrm{NF}$ at $20 \mathrm{bar}$} \\
\hline & $\mathrm{F}=220$ & $\mathrm{R}=120$ & $\mathrm{cf}=1.83$ & $P=100$ & $\mathrm{~F}=100$ & $\mathrm{R}=74$ & $\mathrm{cf}=1.35$ & $\mathrm{P}=26$ \\
\hline & \multicolumn{4}{|l|}{ RO at 50 bar } & \multicolumn{4}{|c|}{ NF at 30 bar } \\
\hline & $\mathrm{F}=220$ & $R=130$ & $\mathrm{cf}=1.69$ & $\mathrm{P}=90$ & $\mathrm{~F}=100$ & $R=28$ & $\mathrm{cf}=3.57$ & $\mathrm{P}=72$ \\
\hline
\end{tabular}

$\mathrm{F}$-feed; R-retentate; $\mathrm{P}$ - permeate volume (in $\mathrm{mL}$ ); cf-concentration factor. 
The trials were planned such that about 50\% water recovery was achieved from each stage of the schemes. Feed volume for second stage in each scheme was fixed at $100 \mathrm{~mL}$. Therefore, the first stage was operated so as to obtain $120 \mathrm{~mL}$ of desired feed (NF permeate in scheme 1 or RO retentate in scheme 2) for the second stage. $20 \mathrm{~mL}$ of the collected $120 \mathrm{~mL}$ was reserved for making the analyses. Samples of the different streams (F, R, and P) from each experiment were analyzed for $\mathrm{N}_{-} \mathrm{NH}_{4}{ }^{+}$, TIC, and TOC concentrations; Abs254; and conductivity. All analyses were carried out as in Table 4 following the German standard methods [37]. The parameters chosen to be analyzed would enable the characterization of rejection capacities of the membranes for organic (using TOC and Abs254 values) and inorganic solutes (using conductivity and $\mathrm{N}_{-} \mathrm{NH}_{4}{ }^{+}$values).

Table 4. Measured parameters and analytical procedures.

\begin{tabular}{ccc}
\hline Parameter & Instrument & Standard Method \\
\hline Abs254 & Jasco-V-550 UV-vis spectrophotometer & DIN 38404-3:2005-07 \\
Ammonia-N & Jasco-V-550 UV-vis spectrophotometer & DIN 38406-5:1983-10 \\
Conductivity & Greisinger-GLF 100 conductivity meter & DIN EN 27888:1993-11 \\
TIC \& TOC & Analytik Jena-Multi N/C 3000 analyzer & DIN EN 1484:1997-08 \\
COD & Hach-LCK 314 cuvette/DR3900 photometer & DIN 38409-H41-H44 \\
\hline
\end{tabular}

Abs254-absorbance at $254 \mathrm{~nm}$; TIC—total inorganic carbon; TOC—total organic carbon; COD—chemical oxygen demand.

\section{Results and Discussion}

\subsection{Comparison of Water Transport}

Table 5 shows the measured values for temperature corrected pure water fluxes $\left(\mathrm{J}_{\mathrm{W}}\right)$ and permeabilities $\left(\mathrm{K}_{\mathrm{W}}\right)$ for $\mathrm{NF} 270$ and SW30HR membranes at steady operating conditions. The effect of operating pressure (OP) on membrane compaction and the resulting negative impact on water permeability can be seen in Table 5. Several other studies [19,38-40] have reported decrease in water permeabilities due to membrane compaction with increase in operating pressure. The clean water permeability of NF270 membrane observed in this work is consistent with the values found in literature $[41,42]$.

Table 5. Measured pure water fluxes, $\mathrm{J}_{\mathrm{w}}\left(\right.$ in $\mathrm{L} \cdot \mathrm{m}^{-2} \cdot \mathrm{h}^{-1}$ ) and permeabilities, $\mathrm{K}_{\mathrm{w}}\left(\right.$ in $\mathrm{L} \cdot \mathrm{m}^{-2} \cdot \mathrm{h}^{-1} \cdot \mathrm{bar}^{-1}$ ) of the membranes at different operating pressures.

\begin{tabular}{ccccccccc}
\hline \multirow{2}{*}{ Membrane } & \multicolumn{2}{c}{ OP $=\mathbf{2 5}$ Bar } & \multicolumn{2}{c}{ 35 Bar } & \multicolumn{2}{c}{$\mathbf{5 5 \text { Bar }}$} & \multicolumn{2}{c}{$\mathbf{6 5 \text { Bar }}$} \\
\cline { 2 - 11 } & $\mathbf{J}_{\mathbf{w}}$ & $\mathbf{K}_{\mathbf{w}}$ & $\mathbf{J}_{\mathbf{w}}$ & $\mathbf{K}_{\mathbf{w}}$ & $\mathbf{J}_{\mathbf{w}}$ & $\mathbf{K}_{\mathbf{w}}$ & $\mathbf{J}_{\mathbf{w}}$ & $\mathbf{K}_{\mathbf{w}}$ \\
\hline NF270 & $306 \pm 3$ & $12.2 \pm 0.1$ & $373 \pm 1$ & $10.6 \pm 0.1$ & - & - & - & - \\
SW30HR & - & - & - & - & $80.4 \pm 3.2$ & $1.46 \pm 0.06$ & $77.4 \pm 1$ & $1.19 \pm 0.01$ \\
\hline
\end{tabular}

Using the experimentally determined values for pure water permeability and initial permeate flux of raw leachate with SW30HR membrane at respective operating pressures, the osmotic pressure $(\pi)$ of raw leachate was calculated to be $14.36 \pm 0.24$ bar (using the relation $\pi=\mathrm{OP}-\mathrm{J}_{\mathrm{w}} / \mathrm{K}_{\mathrm{w}}$ ). A theoretical approximation for osmotic pressure contributions from: inorganic electrolytes (Table 1) using van't Hoff's formula $\left(\pi=\Sigma \mathrm{nRTC}_{\mathrm{s}}\right.$ where $\mathrm{C}_{\mathrm{s}}$ is electrolyte concentration in $\mathrm{mol} / \mathrm{m}^{3}, \mathrm{n}$ is the no. of ions contained in the electrolyte of interest, $\mathrm{R}=8.3142 \mathrm{~J} \cdot \mathrm{K}^{-1} \cdot \mathrm{mol}^{-1}$ and $\mathrm{T}=298.15 \mathrm{~K}$ ) [43], and that from organic solutes using the empirical relation $(\pi=0.00311 \times \mathrm{COD} \times 1.01325)$ reported by Chianese et al. [8] and the measured COD of raw leachate $=980 \pm 23 \mathrm{mg} / \mathrm{L}$ gives $9.83 \mathrm{bar}$ and $3.09 \mathrm{bar}$, respectively, totaling to 12.92 bar.

Figure 3 depicts the permeate fluxes and water conversion factors (WCFs) obtained at different operating pressures for NF and RO stages in scheme 1, wherein the NF stage treated the synthetic raw leachate and its NF permeate was treated by RO. Figure 4 shows the determined permeate fluxes and WCFs with scheme 2, wherein the synthetic raw leachate was first treated by $\mathrm{RO}$ and the $\mathrm{RO}$ retentate was further handled using NF. 
The initial sharp decrease in flux during nanofiltration (see Figures $3 \mathrm{a}$ and $4 \mathrm{~b}$ ) compared to RO stages should be attributed to concentration polarization (and subsequent fouling) resulting from the high initial permeate fluxes offered by NF membrane; whereas the observed gradual decline in flux thereafter is due to increase in osmotic pressure of the solution in the filtration cell. Due to the initial high permeate fluxes and thus, high rejection rates of organics (i.e., entities (organic molecules/ions) rejected per unit time), combined with the fact that the trials were conducted in deposition mode-with limited ability of the stirrer inside the filtration cell to realize effective transport of rejected entities from the membrane surface to the bulk, it is likely that concentration polarization resulting in higher fouling tendencies caused the observed initial sharp decline. On the other hand, due to the fact that the permeate fluxes in the RO stage of RO-NF were lower in comparison, a sharp initial flux decline was not observed.

$\mathrm{NF}$ and RO stages in schemes 1 and 2, respectively, treated raw leachate which has a large amount of organics, whose contribution to osmotic pressure at similar concentrations is much larger than that of inorganic salts [8]. It is interesting to note that the difference between permeate fluxes achieved with higher and lower operating pressures in Figures $3 \mathrm{a}$ and $4 \mathrm{a}$ is marginal, compared to the expected and marked difference to be seen in Figure 3b. Although in both these cases, the permeate fluxes were initially slightly higher at higher operating pressures (in comparison to lower operating pressure), they gradually became smaller. This is likely due to a combination of two reasons: membrane compaction (due to compaction, water permeability is lowered, the flux does not increase linearly with increase in operating pressure) and increased concentration polarization (and thus increased deposition or fouling) due to high TOC content in feed (organics concentration on the surface of the membrane operated with higher pressure can be higher, since the permeate flux was initially slightly higher for higher pressure).
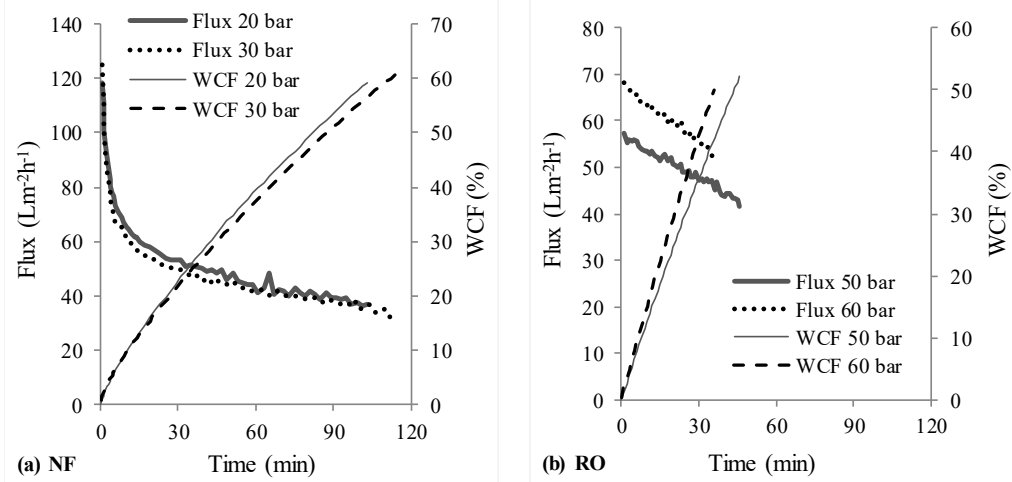

Figure 3. Measured permeate flux and WCF-NF followed by RO (scheme 1, NF $\rightarrow$ RO).
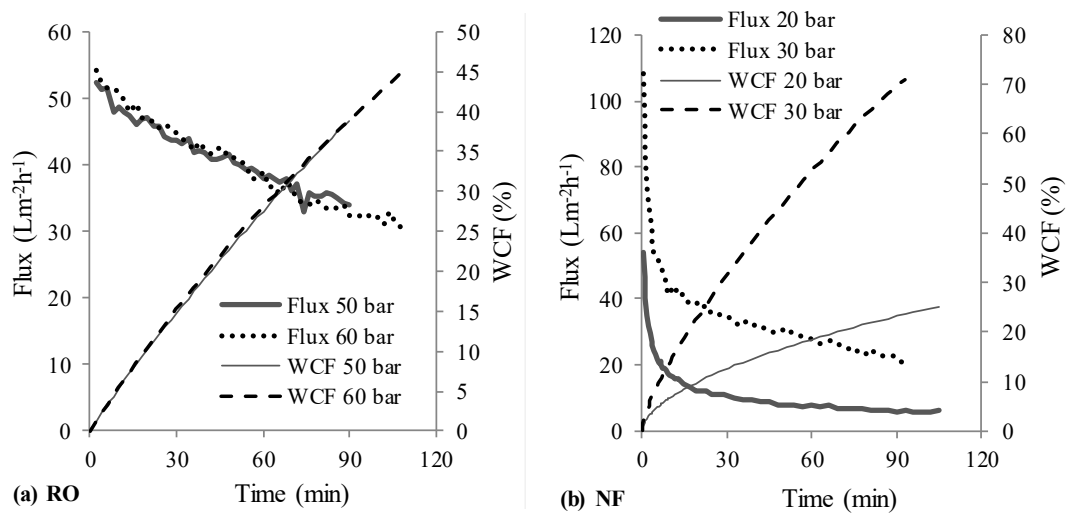

Figure 4. Measured permeate flux and WCF-RO followed by NF (scheme 2, RO $\rightarrow$ NF). 
On the other hand, a large difference in permeate fluxes at 20 and 30 bar pressures was to be seen in the NF stage treating RO concentrate (see Figure 4b). This should be due to the fact that the osmotic pressure of $\mathrm{RO}$ retentate would have been almost twice of that of the raw leachate. Osmotic pressure for nanofiltration will be lower than that for reverse osmosis, if some solutes in the feed can permeate the NF membrane [44]. As a result, the driving force (OP- $\pi$ ) would be smaller for operation at 20 bar than at 30 bar. Consequently, lower fluxes were recorded with 20 bar. Furthermore, it is interesting to see that the permeate flux (after the initial steady decline) at 30 bar in Figure $4 \mathrm{~b}$ (from 40 to $20 \mathrm{~L} \cdot \mathrm{m}^{-2} \cdot \mathrm{h}^{-1}$ ) is roughly $50-70 \%$ of that in Figure 3 a (from 60 to $40 \mathrm{~L} \cdot \mathrm{m}^{-2} \cdot \mathrm{h}^{-1}$ ). This supports the notion that the osmotic pressure of $\mathrm{RO}$ retentate in scheme 2 was roughly two times that of raw leachate.

Overall, permeate fluxes from each stage in scheme 1 were clearly higher than that obtained with scheme 2, which can be seen from Figures 3 and 4. For NF and RO operated with 30 and 50 bar pressures respectively, a total of $176 \mathrm{~mL}$ permeate was recovered from both stages (Table 3) with scheme 1 in about $160 \mathrm{~min}$, whereas it took about $200 \mathrm{~min}$ for recovering $162 \mathrm{~mL}$ permeate with scheme 2. This would translate to lower energy (or operating cost) and membrane area (or time) requirements as advantages of scheme 1 over scheme 2 .

\subsection{Comparison of Solute Transport}

Tables 6 and 7 show the measured values for the different parameters analyzed in the feed, retentate, and permeate samples from the experiments in schemes 1 and 2, respectively. TOC was measured by the difference method. Therefore, the measured TOC concentrations in permeate samples may not be very accurate (as TIC > TOC) [37]. Absorbance at $254 \mathrm{~nm}$ can be used as surrogate for TOC concentrations [45] in permeate samples. Abs254 values of samples expected to contain high TOC concentrations (raw leachate, all NF retentates, and RO retentates from scheme 2), were measured after diluting them 231 times so as to avoid sub-estimation of absorbance.

Table 6. Measured parameters in feed, retentate and permeate samples from scheme $1-\mathrm{NF}$ (20 bar) $\rightarrow$ $\mathrm{RO}(60$ bar) and NF (30 bar) $\rightarrow$ RO (50 bar).

\begin{tabular}{|c|c|c|c|c|c|c|c|c|c|}
\hline \multirow{2}{*}{ Parameter } & \multirow{2}{*}{ Raw Leachate } & \multicolumn{2}{|c|}{ NF Retentate } & \multicolumn{2}{|c|}{ NF Permeate } & \multicolumn{2}{|c|}{ RO Retentate } & \multicolumn{2}{|c|}{ RO Permeate } \\
\hline & & $P=20 \mathrm{Bar}$ & 30 & 20 & 30 & 50 & 60 & 50 & 60 \\
\hline Abs 254 & $0.15^{*} \pm 0.01$ & $0.32 *$ & 0.37 * & 0.05 & 0.04 & 0.10 & 0.07 & 0.01 & 0.01 \\
\hline TOC $(\mathrm{mg} / \mathrm{L})$ & $398 \pm 15$ & 832 & 1046 & $<5$ & $<5$ & $<10$ & $<10$ & $<1$ & $<1$ \\
\hline TIC (mg/L) & $286 \pm 18$ & 514 & 502 & 138 & 147 & 257 & 240 & 12 & 16 \\
\hline $\mathrm{N}-\mathrm{NH}_{4}+(\mathrm{mg} / \mathrm{L})$ & $404 \pm 28$ & 488 & 600 & 294 & 315 & 595 & 530 & 27 & 18 \\
\hline Conductivity $(\mathrm{mS} / \mathrm{cm})$ & $24.6 \pm 0.1$ & 29.8 & 32.8 & 18.2 & 17.5 & 34.6 & 33.9 & 0.36 & 0.34 \\
\hline
\end{tabular}

Table 7. Measured parameters in feed, retentate and permeate samples from scheme 2 - $\mathrm{RO}$ (50 bar) $\rightarrow$ NF (30 bar) and RO (60 bar) $\rightarrow$ NF (20 bar).

\begin{tabular}{cccccccccc}
\hline \multirow{2}{*}{ Parameter } & \multirow{2}{*}{ Raw Leachate } & \multicolumn{2}{c}{ RO Retentate } & \multicolumn{2}{c}{ RO Permeate } & \multicolumn{2}{c}{ NF Retentate } & \multicolumn{2}{c}{ NF Permeate } \\
\cline { 3 - 9 } & & $\mathbf{P}=\mathbf{5 0}$ Bar & $\mathbf{6 0}$ & $\mathbf{5 0}$ & $\mathbf{6 0}$ & $\mathbf{2 0}$ & $\mathbf{3 0}$ & $\mathbf{2 0}$ & $\mathbf{3 0}$ \\
\hline Abs254 & $0.15^{*} \pm 0.01$ & $0.24^{*}$ & $0.27 *$ & 0.01 & 0.01 & $0.27^{*}$ & $0.72 *$ & 0.44 & 0.09 \\
$\mathrm{TOC}(\mathrm{mg} / \mathrm{L})$ & $398 \pm 15$ & 656 & 751 & $<1$ & $<1$ & 741 & 1972 & n.a. & $<10$ \\
$\mathrm{TIC}(\mathrm{mg} / \mathrm{L})$ & $286 \pm 18$ & 444 & 445 & 13 & 12 & 489 & 774 & 270 & 225 \\
$\mathrm{~N}-\mathrm{NH}_{4}^{+}(\mathrm{mg} / \mathrm{L})$ & $404 \pm 28$ & 688 & 668 & 29 & 16 & 649 & 932 & 555 & 543 \\
Conductivity $(\mathrm{mS} / \mathrm{cm})$ & $24.6 \pm 0.1$ & 37.6 & 42.5 & 0.41 & 0.36 & 40.3 & 49.2 & 36.0 & 30.2 \\
\hline
\end{tabular}

* After 231 times dilution (otherwise without dilution); n.a.- not available. 
NF270 is a loose hydrophilic membrane with a molecular weight cut-off of about $200 \mathrm{Da}$ and a high water permeability, showing high and low-to-high rejection capacities for organic solutes and inorganic ions, respectively [41,46-48]. These reasons explain the relationships to be seen between the values for different parameters measured in feed, retentate and permeate samples (Tables 6 and 7) which correspond to the concentration factors (ratio of feed volume to retentate volume) achieved in the respective trials (see Table 3).

For instance, TOC and Abs254 values in NF permeate (at 30 bar in scheme 1) were quite low since NF270 can reject organics effectively and in NF retentate were roughly 2.5 times the values measured in raw leachate, comparable to the concentration factor of 2.6 obtained in that trial. On the other hand, for the same experiment, rejections for $\mathrm{N}_{-} \mathrm{NH}_{4}{ }^{+}$and $\mathrm{TIC}$ (predominantly $\mathrm{HCO}_{3}{ }^{-}$) ranged from $20 \%$ to $60 \%$, consistent with rejection capacities of NF270 for monovalent ions reported in literature [48-50]. Similarly, the measured values for different parameters in $\mathrm{RO}$ retentate and permeate also matched the concentration factors and expected rejections to a good extent.

It is to be emphasized that sharp demarcations and accurate estimations for rejection of solutes cannot be made from these experiments, since they were performed in dead-end mode, in bench scale, and as single trials. However, the aim of these measurements has not been to just characterize the rejection capacities accurately, but also to discuss the potential merits or demerits of the two integration options.

\subsection{NF-RO vs. RO-NF}

Figure 5 compares some treatment perspectives for the NF-RO scheme with the prospective upgrade (based on [18]) of the leachate treatment system using RO-NF at the Ihlenberg landfill site. The schematic illustrates the potential options for combining different treatment methods and distinguishes the advantages of NF-RO compared to RO-NF strategy-as per the aim of this work. It can be seen (also from Table 6) that NF in scheme 1 facilitates the fractionation of pollutants into two streams-permeate stream containing mostly monovalent ions and retentate stream enriched with organic pollutants. As also reported by some other studies [6,51,52], relatively harmless monovalent ions like $\mathrm{Na}^{+}$and $\mathrm{Cl}^{-}$, which are present in significant amounts in landfill leachates, can permeate an NF membrane; while toxic solutes like heavy metals and organic compounds are mostly retained. Due to these reasons, osmotic pressure of each stage in NF-RO is lesser compared to that in RO-NF, which explains the observed superior permeate fluxes (Figures 3 and 4 ) in the former.

On the other hand, in RO-NF the raw leachate is just concentrated several times leading to an increase in osmotic pressure necessitating the use of higher operating pressures, making it energy intensive. Integration of NF with RO (NF-RO) has been reported to be "much more energy-efficient" and to significantly reduce the costs for desalination processes compared to RO alone [20,21]. There is a pressing need for an energy-efficient system as leachate treatment is a long-term process. A closed landfill generates leachate for a timeframe of minimum 30 years, which can be as high as a couple of centuries [1,53,54]. The cost for leachate treatment in Germany has been evaluated to be in the range $€ 10-70$ per $\mathrm{m}^{3}$ leachate [55], which forms about $25-30 \%$ of the total aftercare costs [53]. 


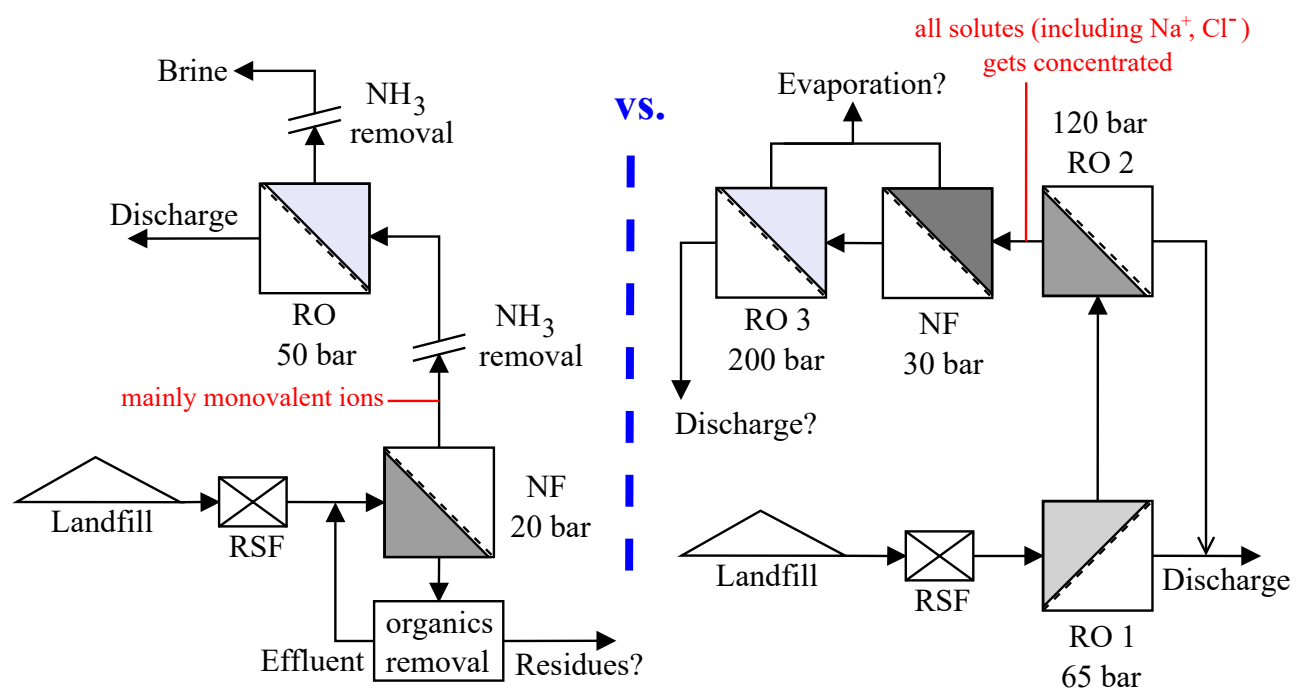

Figure 5. Comparison of: NF-RO-plausible operating pressures and perspectives on integration options (left); and process chain at the landfill site for leachate treatment using RO-NF (right).

High-pressure membrane processes alone cannot treat landfill leachates completely and efficiently $[23,28,31,32,56,57]$, since NF and RO only enrich most of the contaminants in the retentate stream. In other words, a combination with other physical-chemical and/or biological processes is necessary for the removal or degradation of the contaminants. From this point of view, NF placed before RO can offer some other advantages, besides the reduction in energy requirements, operation and maintenance costs.

Nanofiltration placed before reverse osmosis can provide greater flexibility for ammonia removal, since the organic compounds can be selectively separated. Ramaswami et al. [35] reported the ability to recover ammonia from nanofiltration permeate of raw leachate as clean and useable struvite, which can be sold as a fertilizer. Since organics and hardness contents in the NF permeate are low, stripping of ammonia from RO retentate of NF permeate can be accomplished without significant foaming and scaling problems, which is often faced during ammonia stripping from leachates [58-60]. Should biological ammonia removal from raw leachate be challenging due to inhibition from organics [61-63], nanofiltration might provide a solution to this scenario offering a less complex permeate for biological treatment. Organic pollutants which are enriched in the NF retentate can be treated appropriately using other physical-chemical processes such as coagulation/electrocoagulation-flocculation, ozonation followed by biological treatment, etc. $[3,31,33,56,64]$.

On the other hand with RO-NF scheme, despite the requirement for higher operating pressures, the possibility for integration with other physical-chemical or biological processes becomes challenging or limited. At the Ihlenberg landfill, the raw leachate (see composition in Table 2) gets about five times concentrated by the two-stage reverse osmosis (about 30, 15, 4, and $3 \mathrm{~g} / \mathrm{L} \mathrm{Cl}^{-}, \mathrm{Na}^{+}$, TOC and $\mathrm{NH}_{4}{ }^{+}-\mathrm{N}$, respectively, in RO retentate). For this scenario for instance, biological treatment of $\mathrm{RO}$ retentate or its NF permeate would be challenging due to high salinity and the purity of struvite precipitated from the NF permeate of RO-NF would be lower [35].

Investigation of fouling/scaling tendencies was not in the scope of this study and needs to be addressed in larger scale (in lab or pilot-scale) under real-time working conditions (with the actual landfill leachate in crossflow mode). It may be however, said in general that the fouling and scaling of RO membrane in NF-RO would be reduced (since the NF stage can remove most of the humic substances, and $\mathrm{Ca}^{2+}, \mathrm{SO}_{4}{ }^{2-}$, and other di/multivalent ions) compared to that in RO-NF. It is recommendable to apply viable pre-treatment or integration strategies for also minimizing the fouling 
of NF membrane in NF-RO configuration. Due to the experimental constraints of this study, the specific energy requirements could not be presented in this paper.

\section{Conclusions}

Monovalent ions present in landfill leachates can permeate an NF membrane whereas organic solutes and other electrolytes are mostly rejected. Thus, both NF and RO stages in NF-RO can be operated at lower pressures compared to NF and RO stages in RO-NF. For similar operating conditions, individual stages in NF-RO provided higher water fluxes than those in RO-NF, showing NF-RO to be more energy efficient. Only a combination of biological and/or physical-chemical technologies together with membrane processes can fulfil complete and efficient treatment of landfill leachates. The ability of the NF stage in NF-RO to fractionate monovalent ions including $\mathrm{NH}_{4}{ }^{+}$from other pollutants can be advantageous for realizing an effective and integrated system for treating a landfill leachate.

Acknowledgments: The authors acknowledge the Institute of Water Resources and Water Supply at TUHH for offering their experimental setup for this study, Holger Gulyas for proofreading the manuscript, and RTS Rochem Technical Services GmbH for funding the Ph.D. studies of Sreenivasan Ramaswami. This publication was supported by the German Research Foundation (DFG) and the Hamburg University of Technology (TUHH) in the funding program "Open Access Publishing".

Author Contributions: Sreenivasan Ramaswami, Joachim Behrendt, and Ralf Otterpohl conceived this comparative study. Sreenivasan Ramaswami designed and performed the experiments, analyzed the data, and wrote the paper. Joachim Behrendt and Ralf Otterpohl were involved in the scientific discussions. All authors have approved this submission.

Conflicts of Interest: The authors declare no conflict of interest.

\section{References}

1. Kjeldsen, P.; Barlaz, M.A.; Rooker, A.P.; Baun, A.; Ledin, A.; Christensen, T.H. Present and Long-Term Composition of MSW Landfill Leachate: A Review. Crit. Rev. Environ. Sci. Technol. 2002, 32, 297-336. [CrossRef]

2. Gao, J.; Oloibiri, V.; Chys, M.; Audenaert, W.; Decostere, B.; He, Y.; Van Langenhove, H.; Demeestere, K.; Van Hulle, S.W.H. The present status of landfill leachate treatment and its development trend from a technological point of view. Rev. Environ. Sci. Bio/Technol. 2015, 14, 93-122. [CrossRef]

3. Renou, S.; Givaudan, J.G.; Poulain, S.; Dirassouyan, F.; Moulin, P. Landfill leachate treatment: Review and opportunity. J. Hazard. Mater. 2008, 150, 468-493. [CrossRef] [PubMed]

4. Wiszniowski, J.; Robert, D.; Surmacz-Gorska, J.; Miksch, K.; Weber, J.V. Landfill leachate treatment methods: A review. Environ. Chem. Lett. 2006, 4, 51-61. [CrossRef]

5. Chian, E.S.K.; DeWalle, P.B. Sanitary Landfill Leachates and Their Treatment. J. Environ. Eng. Div. 1976, 102, 411-431.

6. Linde, K.; Jönsson, A.; Wimmerstedt, R. Treatment of three types of landfill leachate with reverse osmosis. Desalination 1995, 101, 21-30. [CrossRef]

7. Peters, T.A. Purification of landfill leachate with reverse osmosis and nanofiltration. Desalination 1998, 119, 289-293. [CrossRef]

8. Chianese, A.; Ranauro, R.; Verdone, N. Treatment of landfill leachate by reverse osmosis. Water Res. 1999, 33, 647-652. [CrossRef]

9. Peters, T.A. Purification of landfill leachate with membrane filtration. Filtr. Sep. 1998, 35, 33-36. [CrossRef]

10. Šír, M.; Podhola, M.; Patočka, T.; Honzajková, Z.; Kocurek, P.; Kubal, M.; Kuraš, M. The effect of humic acids on the reverse osmosis treatment of hazardous landfill leachate. J. Hazard. Mater. 2012, 207, 86-90. [CrossRef] [PubMed]

11. Barber, C.; Maris, P.J. Recirculation of leachate as a landfill management option: Benefits and operational problems. Q. J. Eng. Geol. Hydrogeol. 1984, 17, 19-29. [CrossRef]

12. Reinhart, D.R.; Basel Al-Yousfi, A. The Impact of Leachate Recirculation on Municipal Solid Waste Landfill Operating Characteristics. Waste Manag. Res. 1996, 14, 337-346. [CrossRef]

13. Šan, I.; Onay, T.T. Impact of various leachate recirculation regimes on municipal solid waste degradation. J. Hazard. Mater. 2001, 87, 259-271. [CrossRef] 
14. Sponza, D.T.; Ağdağ, O.N. Impact of leachate recirculation and recirculation volume on stabilization of municipal solid wastes in simulated anaerobic bioreactors. Process Biochem. 2004, 39, 2157-2165. [CrossRef]

15. Robinson, H.D.; Maris, P.J. The Treatment of Leachates from Domestic Waste in Landfill Sites. J. Water Pollut. Control Fed. 1985, 57, 30-38.

16. DEPV, Deponieverordnung. Verordnung über Deponien und Langzeitlager; Deponieverordnung vom 27. April 2009 (BGBl. I S. 900); DEPV, Deponieverordnung: Germany, 2009.

17. Ihlenberger Abfallentsorgungsgesellschaft mbH (IAG). Waste Management is a Matter of Trust (Broschure); Ihlenberger Abfallentsorgungsgesellschaft mbH (IAG): Ihlenberg, Germany, 2012.

18. Rautenbach, R.; Linn, T. High-pressure reverse osmosis and nanofiltration, a "zero discharge" process combination for the treatment of waste water with severe fouling/scaling potential. Desalination 1996, 105, 63-70. [CrossRef]

19. Rautenbach, R.; Linn, T.; Eilers, L. Treatment of severely contaminated waste water by a combination of RO, high-pressure RO and NF-Potential and limits of the process. J. Memb. Sci. 2000, 174, 231-241. [CrossRef]

20. Zhou, D.; Zhu, L.; Fu, Y.; Zhu, M.; Xue, L. Development of lower cost seawater desalination processes using nanofiltration technologies-A review. Desalination 2015, 376, 109-116. [CrossRef]

21. Hilal, N.; Al-Zoubi, H.; Darwish, N.A.; Mohamma, A.W.; Abu Arabi, M. A comprehensive review of nanofiltration membranes: Treatment, pretreatment, modelling, and atomic force microscopy. Desalination 2004, 170, 281-308. [CrossRef]

22. Ushikoshi, K.; Kobayashi, T.; Uematsu, K.; Toji, A.; Kojima, D.; Matsumoto, K. Leachate treatment by the reverse osmosis system. Desalination 2002, 150, 121-129. [CrossRef]

23. Baumgarten, G.; Seyfried, C.F. Experiences and new developments in biological pretreatment and physical posttreatment of landfill leachate. Water Sci. Technol. 1996, 34, 445-453. [CrossRef]

24. Ince, M.; Senturk, E.; Onkal Engin, G.; Keskinler, B. Further treatment of landfill leachate by nanofiltration and microfiltration-PAC hybrid process. Desalination 2010, 255, 52-60. [CrossRef]

25. Košutić, K.; Dolar, D.; Strmecky, T. Treatment of landfill leachate by membrane processes of nanofiltration and reverse osmosis. Desalin. Water Treat. 2015, 55, 2680-2689. [CrossRef]

26. Kwon, O.; Lee, Y.; Noh, S. Performance of the NF-RDM (Rotary Disk Membrane) module for the treatment of landfill leachate. Desalination 2008, 234, 378-385. [CrossRef]

27. Li, G.; Wang, W.; Du, Q. Applicability of nanofiltration for the advanced treatment of landfill leachate. J. Appl. Polym. Sci. 2010, 116, 2343-2347. [CrossRef]

28. Mariam, T.; Nghiem, L.D. Landfill leachate treatment using hybrid coagulation-nanofiltration processes. Desalination 2010, 250, 677-681. [CrossRef]

29. Mohammad, A.W.; Hilal, N.; Pei, L.Y. Treatment of Landfill Leachate Wastewater by Nanofiltration Membrane. Int. J. Green Energy 2004, 1, 251-263. [CrossRef]

30. Rautenbach, R.; Mellis, R. Waste water treatment by a combination of bioreactor and nanofiltration. Desalination 1994, 95, 171-188. [CrossRef]

31. Trebouet, D.; Schlumpf, J.; Jaouen, P.; Quemeneur, F. Stabilized landfill leachate treatment by combined physicochemical-nanofiltration processes. Water Res. 2001, 35, 2935-2942. [CrossRef]

32. Bohdziewicz, J.; Bodzek, M.; Górska, J. Application of pressure-driven membrane techniques to biological treatment of landfill leachate. Process Biochem. 2001, 36, 641-646. [CrossRef]

33. Dolar, D.; Košutić, K.; Strmecky, T. Hybrid processes for treatment of landfill leachate: Coagulation/UF/NF-RO and adsorption/UF/NF-RO. Sep. Purif. Technol. 2016, 168, 39-46. [CrossRef]

34. Di Palma, L.; Ferrantelli, P.; Merli, C.; Petrucci, E. Treatment of industrial landfill leachate by means of evaporation and reverse osmosis. Waste Manag. 2002, 22, 951-955. [CrossRef]

35. Ramaswami, S.; Behrendt, J.; Wang, G.; Eggers, S.; Otterpohl, R. Combining magnesium ammonium phosphate precipitation with membrane processes for ammonia removal from methanogenic leachates. Water Environ. J. 2016, 30, 218-226. [CrossRef]

36. GE Water Temperature Correction Factor Guidelines. Available online: https://www.gewater.com/kcpgue st/salesedge/documents/Manuals_Cust/Americas /English/Temperature_Correction_Factor_Guideline s.pdf (accessed on 29 July 2016).

37. GDCh \& DIN. English: German Standard Methods for the Examination of Water, Waste Water and Sludge; Wasserchemische Gesellschaft in der GDCh und Normenausschuss Wasserwesen des Deutsches Institut für Normung e.V., Ed.; Beuth Verlag GmbH: Berlin, Germany, 2015; ISBN 9783410130284. 
38. McGovern, R.K.; McConnon, D.; Lienhard, V.J.H. The effect of very high hydraulic pressure on the permeability of reverse osmosis membranes. In IDA World Congress on Desalination and Water Reuse; International Desalination Association: San Diego, CA, USA, 2015.

39. Pendergast, M.T.M.; Nygaard, J.M.; Ghosh, A.K.; Hoek, E.M.V. Using nanocomposite materials technology to understand and control reverse osmosis membrane compaction. Desalination 2010, 261, 255-263. [CrossRef]

40. Peterson, R.A.; Greenberg, A.R.; Bond, L.J.; Krantz, W.B. Use of ultrasonic TDR for real-time noninvasive measurement of compressive strain during membrane compaction. Desalination 1998, 116, 115-122. [CrossRef]

41. Al-Rashdi, B.A.M.; Johnson, D.J.; Hilal, N. Removal of heavy metal ions by nanofiltration. Desalination 2013, 315, 2-17. [CrossRef]

42. Moons, K.; Van der Bruggen, B. Removal of micropollutants during drinking water production from surface water with nanofiltration. Desalination 2006, 199, 245-247. [CrossRef]

43. Janáček, K.; Sigler, K. Osmotic pressure: Thermodynamic basis and units of measurement. Folia Microbiol. (Praha) 1996, 41, 2-9. [CrossRef]

44. DOW FILMTEC ${ }^{\mathrm{TM}}$ Membranes-Basics of RO and NF: Principle of Reverse Omosis and Nanofiltration. Available online: http:/ / msdssearch.dow.com/PublishedLiteratureDOWCOM/dh_003b/0901b8038003b 454.pdf?filepath=liquidseps/pdfs /noreg/609-02003.pdf\&fromPage=GetDoc (accessed on 4 August 2016).

45. Summers, R.S.; Cornel, P.K.; Roberts, P.V. Molecular size distribution and spectroscopic characterization of humic substances. Sci. Total Environ. 1987, 62, 27-37. [CrossRef]

46. Hilal, N.; Al-Abri, M.; Al-Hinai, H.; Abu-Arabi, M. Characterization and retention of NF membranes using PEG, HS and polyelectrolytes. Desalination 2008, 221, 284-293. [CrossRef]

47. Lopes, M.P.; Matos, C.T.; Pereira, V.J.; Benoliel, M.J.; Valério, M.E.; Bucha, L.B.; Rodrigues, A.; Penetra, A.I.; Ferreira, E.; Cardoso, V.V.; et al. Production of drinking water using a multi-barrier approach integrating nanofiltration: A pilot scale study. Sep. Purif. Technol. 2013, 119, 112-122. [CrossRef]

48. Shen, J.; Schäfer, A.I. Factors affecting fluoride and natural organic matter (NOM) removal from natural waters in Tanzania by nanofiltration/reverse osmosis. Sci. Total Environ. 2015, 527-528, 520-529. [CrossRef] [PubMed]

49. Košutić, K.; Furač, L.; Sipos, L.; Kunst, B. Removal of arsenic and pesticides from drinking water by nanofiltration membranes. Sep. Purif. Technol. 2005, 42, 137-144. [CrossRef]

50. Tang, C.Y.; Fu, Q.S.; Criddle, C.S.; Leckie, J.O. Effect of Flux (Transmembrane Pressure) and Membrane Properties on Fouling and Rejection of Reverse Osmosis and Nanofiltration Membranes Treating Perfluorooctane Sulfonate Containing Wastewater. Environ. Sci. Technol. 2007, 41, 2008-2014. [CrossRef] [PubMed]

51. Linde, K.; Jönsson, A.-S. Nanofiltration of salt solutions and landfill leachate. Desalination 1995, 103, $223-232$. [CrossRef]

52. Urase, T.; Salequzzaman, M.; Kobayashi, S.; Matsuo, T.; Yamamoto, K.; Suzuki, N. Effect of high concentration of organic and inorganic matters in landfill leachate on the treatment of heavy metals in very low concentration level. Water Sci. Technol. 1997, 36, 349-356. [CrossRef]

53. Heyer, K.-U.; Hupe, K.; Stegmann, R. Landfill Aftercare-Scope for Actions, Duration, Costs and Quantitative Criteria for the Completion. In Proceedings Sardinia 2005, Tenth International Waste Management and Landfill Symposium; CISA: Cagliari, Italy, 2005.

54. Scharff, H.; Crest, M. ISWA Key Issue Paper on Landfill Aftercare; International Solid Waste Association: Vienna, Austria, 2013.

55. Stegmann, R.; Heyer, K.-U.; Cossu, R. Leachate Treatment. In Proceedings Sardinia 2005, Tenth International Waste Management and Landfill Symposium; CISA: Cagliari, Italy, 2005.

56. Top, S.; Sekman, E.; Hoşver, S.; Bilgili, M.S. Characterization and electrocaogulative treatment of nanofiltration concentrate of a full-scale landfill leachate treatment plant. Desalination 2011, 268, 158-162. [CrossRef]

57. Wang, G.; Fan, Z.; Wu, D.; Qin, L.; Zhang, G.; Gao, C.; Meng, Q. Anoxic/aerobic granular active carbon assisted MBR integrated with nanofiltration and reverse osmosis for advanced treatment of municipal landfill leachate. Desalination 2014, 349, 136-144. [CrossRef]

58. Li, X.Z.; Zhao, Q.L.; Hao, X.D. Ammonium removal from landfill leachate by chemical precipitation. Waste Manag. 1999, 19, 409-415. [CrossRef] 
59. Liao, P.H.; Chen, A.; Lo, K.V. Removal of nitrogen from swine manure wastewaters by ammonia stripping. Bioresour. Technol. 1995, 54, 17-20. [CrossRef]

60. Silva, A.C.; Dezotti, M.; Sant'Anna, G.L. Treatment and detoxification of a sanitary landfill leachate. Chemosphere 2004, 55, 207-214. [CrossRef] [PubMed]

61. Aktas, Ö.; Çeçen, F. Nitrification inhibition in landfill leachate treatment and impact of activated carbon addition. Biotechnol. Lett. 2001, 23, 1607-1611. [CrossRef]

62. Ramaswami, S.; Behrendt, J.; Kalyanasundaram, S.; Eggers, S.; Otterpohl, R. Experiences from an investigation on the potential of packed bed reactors for high rate nitrification of mature landfill leachates. J. Water Process Eng. 2018, 22, 59-65. [CrossRef]

63. Horan, N.J.; Gohar, H.; Hill, B. Application of a granular activated carbon-biological fluidised bed for the treatment of landfill leachates containing high concentrations of ammonia. Water Sci. Technol. 1997, 36, 369-375. [CrossRef]

64. Wang, H.; Wang, Y.; Li, X.; Sun, Y.; Wu, H.; Chen, D. Removal of humic substances from reverse osmosis (RO) and nanofiltration (NF) concentrated leachate using continuously ozone generation-reaction treatment equipment. Waste Manag. 2016, 56, 271-279. [CrossRef] [PubMed]

(C) 2018 by the authors. Licensee MDPI, Basel, Switzerland. This article is an open access article distributed under the terms and conditions of the Creative Commons Attribution (CC BY) license (http://creativecommons.org/licenses/by/4.0/). 